\title{
TEMPAT INTERAKSI BERBAGAI MACAM KEBUDAYAAN - JL. GEREJA AYAM
}

\author{
Andi Wijaya ${ }^{1)}$, Dewi Ratnaningrum ${ }^{2)}$ \\ 1)Program Studi S1 Arsitektur, Fakultas Teknik, Universitas Tarumanagara, wijaya.andi992@gmail.com \\ 2) Program Studi S1 Arsitektur, Fakultas Teknik, Universitas Tarumanagara, dewir@ft.untar.ac.id
}

\begin{abstract}
Abstrak
Seiring berkembangnya waktu pusat pembelanjaan Pasar Baru ditinggalkan dikarenakan banyaknya pusat perbelanjaan modern yang mulai bermunculan di Jakarta. Hal ini menyebabkan pusat perbelanjaan berlomba-lomba menarik pengunjung dengan berbagai cara, seperti tempat transaksi sekaligus juga sebagai rekreasi keluarga, menjadi tempat hiburan, dan dapat menjadi Third Place di kota-kota besar seperti Jakarta. Sehingga membuat pusat perbelanjaan yang berkonsep lama menjadi sepi. Penurunan pengunjung di Pasar Baru berdampak ke daerah sekitar Pasar Baru yang membuat tidak seramai dahulu dan terlihat seperti di tinggalkan. Hal ini bertolak belakang pada kondisi Pasar Baru dahulu. Padahal Pasar Baru mempunyai potensi besar. Jika dilihat di sekitar Pasar Baru keberagaman etnis di sana sangatlah kental dan terdapat 3 etnis yang sangat dominan yaitu, etnis India, Tionghoa, dan Betawi. kemudian keberagaman etnis di sana membuat Pasar Baru kaya akan kebudayaan. Oleh karena itu tujuan dari penelitian ini adalah menciptakan sebuah wadah untuk menampung kegiatan-kegiatan kebudayaan serta dapat menarik minat pengunjung Pasar Baru dengan memasukan berbagai teori seperti Third Place. Adapun metode yang dipakai yaitu melakukan studi observasi dan penyebaran kuesioner, serta mempelajari berbagai kebutuhan dari masyarakat sekitar dan membuat program-program yang sesuai dengan hasil survei observasi untuk menyesuaikan kebutuhan masyarakat sekitar. Maka dari itu program ini diharapkan dapat menjadi solusi untuk permasalahan menurunnya pengunjung Pasar Baru serta dapat menjadi Third place bagi masyarakat di sekitar kawasan Pasar Baru.
\end{abstract}

\section{Kata kunci: etnis; keberagaman; kebudayaan}

\begin{abstract}
As the time for the Shopping Center grew Pasar Baru to be abandoned because of the many modern shopping centers that began to appear in Jakarta. This causes shopping centers to compete with visitors in a variety of ways, such as transactions as well as family recreation, entertainment venues, and can become Third Place in big cities like Jakarta. So that makes shopping centers that are old concept become quiet. The decline in visitors in Pasar Baru has an impact on the surrounding area Pasar Baru which makes it not as busy as before and looks like it was left behind. This is contrary to the condition Pasar Baru first. Though Pasar Baru has great potential. If you look around Pasar Baru ethnic diversity there is very thick, there are 3 ethnic groups that are very dominant there namely, Indian, Chinese and Betawi ethnic groups. And ethnic diversity there makes Pasar Baru rich in culture. Therefore the purpose of this research is to create a forum to accommodate cultural activities and be able to attract the interest of visitors Pasar Baru by including various theories such as Third Place, as for the method used, namely conducting studies, observations and distributing questionnaires, as well as studying various needs of the surrounding community and making programs in accordance with the results of the observation survey to adjust the needs of the surrounding community, therefore this program is expected to be a solution to the problem of decreasing visitors Pasar Baru and can be a third place for the community in around the area Pasar Baru.
\end{abstract}

Keywords: culture, diversity, ethnicity 


\section{PENDAHULUAN}

Pusat perbelanjaan di kota-kota besar di Indonesia seperti Jakarta saat ini bukan hanya tempat melakukan jual-beli, tetapi juga menjadi pusat kehidupan masyarakat kota. Mal atau pusat perbelanjaan adalah tempat terbuka dekat dengan gedung-gedung di kota yang memiliki tempat untuk berjalan dan berbelanja. Dengan seiringnya waktu, pusat perbelanjaan berkembang menjadi modern, terutama di kota-kota besar seperti Jakarta, banyaknya pembangunan mal membuat pusat pembelanjaan yang berkonsep lama menjadi sepi pengunjung. Dikarenakan mal-mal di Jakarta berlomba untuk menarik pengunjung.

Pertumbuhan mal dari tahun ke tahun terus mengalami peningkatan tiap tahunnya jumlah mal tumbuh 3,9\%. Pada pembangunan mal ditahun 2014 dan 2015 juga lebih banyak terkonsentrasi di Jakarta Barat dan Jakarta Utara. Yang mengejutkan adalah wilayah Bekasi dan Tangerang. Kawasan ini menjadi penyumbang terbesar masing-masing $35 \%$ dan $37 \%$. Dari data-data di atas menyebutkan bahwa pesatnya perkembangan pusat perbelanjaan di kota Jakarta. Hal ini menyebabkan pusat perbelanjaan berlomba-lomba menarik pengunjung dengan berbagai cara, seperti menjadi tempat transaksi sekaligus juga sebagai tempat rekreasi keluarga, menjadi tempat hiburan, dan dapat menjadi "Third Place" di kota-kota besar seperti Jakarta. Sehingga membuat pusat perbelanjaan yang berkonsep lama menjadi sepi.

Salah satu pusat perbelanjaan yang berkonsep lama lama adalah Pasar Baru. Pasar Baru adalah daerah pusat perdagangan terletak di Kelurahan Pasar Baru, Kecamatan Sawah Besar, Jakarta Pusat. Pusat perbelanjaan ini sudah didirikan sejak tahun 1820, dan merupakan pusat perbelanjaan tertua di Jakarta. Pasar Baru dulu terkenal akan keberagaman etnis di sana yang menjual berbagai macam barang seperti tekstil, perhiasan, makanan, dll. Pasar Baru kaya akan kebudayaan-kebudayaan dari berbagai etnis di sana. Akan tetapi sekarang Pasar Baru menjadi sepi pengunjung. Banyaknya bermunculan pusat perbelanjaan modern menjadi salah satu penyebabnya. Penurunan pengunjung di Pasar Baru berdampak ke daerah sekitar Pasar Baru, seperti penutupan Bioskop Globe, Pasar Baru mengalami penurunan target penjualan, kegiatan jual beli di Pasar Baru tidak sampai malam, kawasan Pasar Baru tidak seramai dahulu dan terlihat seperti di tinggalkan. Hal ini bertolak belakang pada kondisi Pasar Baru dahulu. Padahal Pasar Baru mempunyai potensi besar.

Jika dilihat di Pasar Baru keberagaman etnis di sana sangatlah kental, terdapat 3 etnis yang sangat dominan disana yaitu, etnis India, Tionghoa, dan Betawi. Dan keberagaman etnis disana membuat Pasar Baru kaya akan kebudayaan. Oleh karena itu Pembuatan wadah untuk menampung kegiatan-kegiatan kebudayaan serta dapat menarik minat pengunjung Pasar Baru dengan memasukan berbagai teori seperti "Third Place", diharapkan dapat menjadi solusi untuk menurunnya pengunjung Pasar Baru serta berdampak positif bagi masyarakat di sekitar kawasan Pasar Baru.

\section{KAJIAN LITERATUR}

\section{Third Place}

Pengertian Third place menurut Oldenburg. The Great Good Place (1997) menyatakan bahwa First place seseorang sebagai rumah dan tempat tinggal seseorang. Second place adalah tempat bekerja/kantor yang di mana seseorang menghabiskan sebagian besar waktu mereka. Dan pengertian Third place adalah suatu tempat seseorang untuk melepaskan penat dalam rutinitas sehari-harinya sehingga dapat dikatakan Third place Anda adalah tempat di mana seseorang bisa bersenang-senang di depan umum, dan juga di mana seseorang dapat bertemu dengan teman-teman maupun orang asing. Berdasarkan hasil risetnya, Oldenburg. The Great Good Place (1997) mengungkapkan ada 8 karakter yang membentuk Third place yaitu sebagai berikut: 


\section{a. Netral Ground}

Pengunjung Third place tidak memiliki kewajiban apapun untuk berkunjung ke sana. Mereka tidak terikat dengan ketentuan apapun, baik secara keuangan, politik, hukum, serta bebas untuk datang maupun pergi.

b. Leveler

Third place tidak melihat dari pangkat seseorang dalam suatu masyarakat. Status ekonomi atau sosial seseorang tidak penting di sana. Di Third place kesamaan di antara penghuninya sangatlah erat. Maka dari itu tidaklah ada syarat yang akan mencegah seseorang datang ke Third place.

c. Conversation is the main

Obrolan pembicaraan yang menyenangkan adalah fokus utama dari aktivitas di sana, pembicaraan disana bersifat ringan dan lucu. Pembicaraan yang bahagia disana yang ditunggu- tunggu.

d. Accessibility and accomodation

Third place arus bersifat terbuka dan gampang untuk di akses oleh pengunjung di sana. Mereka harus memenuhi kebutuhan pengunjung lainnya, dan semua pengunjung merasakan bahwa kebutuhan yang mereka mau telah terpenuhi.

e. The regulars

Third place memiliki sejumlah pengunjung tetap yang dapat membantu mengatur suasana hati bagi sekitarnya. Pengunjung tetap yang berada di sana juga menarik pendatang baru dan mereka membantu pendatang baru merasa diterima disana.

f. Low profile

Third place secara karakteristik sehat. Yang di artikan sebagai tempat yang dimana tidak memboroskan. Dan Third place tidak bersifat sombong atau antara lain selalu menerima semua jenis individu, di masyarakat.

g. Mood is playful

Pembicaraan di Third place tidak akan pernah ditandai dengan ketegangan atau permusuhan. tempat ini memiliki karakteristik yang membuat bahagia, yang di mana pembicaraan yang bertujuan membuat senang sangat dihargai.

h. Home away from home

Pengunjung yang berada di Third place akan sering mempunyai sifat berbaur. maka mereka merasa di ruang yang sama mereka akan mendapatkan kesenangan batin mereka, dengan menghabiskan waktu bersama-sama di sana.

\section{Architecture in contextual}

Menurut Brent C. Brolin. Architecture in Context 1980, Kontekstual merupakan pembangunan atau perancangan arsitektur dengan mengkaitkan kondisi lingkungan sekitarnya. Bangunan diharapkan memperhatikan dan menghormati lingkungan fisik sekitarnya, serta dapat memliki visual yang berkaitan dengan bangunan, dan bahkan gaya wilayah itu sendiri.

Dalam pembagian arsitektur kontekstual, kontekstual menjadi 2 yaitu kontras, dan harmoni. Adapun arti kontras dan harmoni sebagai berikut:

a. Kontras

Kontras dapat menghidupkan suatu kawasan, yang dimana harus memperhatikan kondisi wilayah itu sendiri. Kontras bangunan modern dan kuno dapat menjadi sebuah harmoni, tetapi tetap memikirkan kondisi sekitar dikarnakan jika tidak memiliki keterkaitan maka akan menimbulkan Shock efek.

b. Harmoni

Dalam melakukan perancangan perlunya di perhatikan harmoni, hal ini untuk menjaga keserasian pada kondisi sekitar. sehingga bangunan yang akan dirancang lebih menunjan kondisi sekitar dari pada berbeda karakter dari bangunan yang sudah ada. 


\section{Responsive Environments}

Menurut Ian Bentley. Responsive Environments: A Manual for Designers (1985). Dalam menciptakan lingkungan yang Responsive, terdapat tujuh aspek yang perlu diperhatikan. Yaitu sebagai berikut:

a. Permeability / Rembesan Jalan

Permeability adalah aksesbilitas dan sirkulasi yang dapat diakses oleh manusia atau kendaraan. Hanya tempat yang terhubung sirkulasi manusia lah yang dapat menawarkan berbagai kegiatan. Berbagai kegiatan membuat kawasan menjadi Responsive. Hal ini membuat perancang harus memikirkan bagaimana sirkulasi dapat membuat kawasan menjadi hidup, seperti mengetahui kemana mereka dapat mencapai ke kawasan atau fungsi lain dan bagaimana cara sirkulasi dapat menghidupkan suatu kawasan.

b. Variety/Variasi

Tempat yang mudah di akses tidak menjamin suatu tempat menjadi ramai dan Responsive. Oleh karna itu perancang harus memikirkan variasi-variasi fungsi dalam menciptakan kawasan yang Responsive di tahap ini perancangan memikirkan berbagai fungsi di kawasan. Perlunya mengetahui terlebih dahulu berbagai permintaan fungsi di kawasan, sehingga dapat menetapkan berapa luas fungsi yang diperlukan, luas bangunan dapat ditetapkan dengan mempertimbangkan fungsi yang ada.

c. Legibility/Mudah dibaca

Dalam melakukan menentukan fungsi suatu kawasan, perancang juga harus mengerti bagaimana masyarakat dapat dengan mudah mengerti tata letaknya. Hal ini dilakukan pada tahap ke tiga dari desain yaitu menciptakan Legibility. Berbagai sirkulasi dan fungsi yang sudah ada diolah, menjadi sebuah kondisi yang mampu membawa masyarakat pada fungsi atau identitas tertentu. Legibility adalah seperti kita dapat mengetahui sesuatu fungsi wilayah dengan hanya merasakannya.

d. Robustness / Kekokohan

Tempat yang dirancang dengan memikirkan berbagai fungsi dapat dilakukan disana serta dapat berganti- ganti fungsi membuat suatu lingkungan yang memiliki berbagai pilihan aktifitas temporer dapat disebut sebagai Robustness. Tujuannya dari Robustness ini adalah untuk membuat adanya organisasi kegiatan yang tidak kalah dengan waktu sehingga fungsi dapat menyesuaikan masa depan. Hal ini membuat kawasan menjadi tidak kalah dengan jaman dikarnakan banyaknya pilihan aktifitas yang terus mengikuti jaman.

e. Visual Appropriateness / Kesesuaian Visual

Perancang harus mengerti bagaimana caranya pengunjung dapat mengerti makna suatu tempat sesuai dengan kondisi penglihatannya. Jika pengunjung mengerti, maka Visual Appropriateness terjadi. Hal ini bertujuan mempengaruhi pengunjung sehingga memiliki kesesuaian visual dengan makna dari tempat tersebut. Makna Visual Appropriateness itu Seperti kita dapat mengetahui pusat pembelanjaan itu untuk kalangan menengahmenengah sampai menengah atas, tanpa ada pemberitahuan mengenai tempat Perbelanjaan itu.

f. Richness / Kekayaan

Dalam tahap ini perancang harus memikirkan bagaimana caranya pengunjung dapat banyak sekali pengalaman atau kesan pada kawasan yang dirancang. tingkat ini disebut richness. Pada tahap ini, perancang harus bisa merincian proyek dengan detail sehingga perancang dapat menciptakan kekayaan rasa, baik secara visual dan non-visual, dan memilih desain yang berkesan, bahan-bahan, dan fungsi yang tepat untuk mencapai Responsive suatu rancangan.

g. Personalisation / Karakteristik Masyarakat

Dengan merancang suatu kawasan yang Responsive, karakteristik masyarakat sekitar perlu diperhatikan juga, karakteristik masyarakat akan menjadikan karakteristik dari kawasan itu sendiri. 


\section{Urban Acupuncture}

Menurut Jaime Lerner dalam bukunya yang berjudul Urban Acupuncture (2004). Dikatakan bahwa dengan adanya suntikan di suatu titik spesifik pada ruang kota dapat berdampak kepada area yang lebih luas di sekitarnya. Konsep tersebut dapat dikatakan sebagai solusi dalam memberikan perubahan yang cepat dan kontekstual pada ruang kota yang bermasalah. Dengan adanya suntikan perancangan ruang publik yang ada pada beberapa titik kota, seberapa kecilnya dapat memiliki dampak yang luas bagi area di sekitarnya. Menurutnya Kota memiliki enery yang komplek dan terus mengalir (complex energy and flows) sejalan dengan perkembangan kota yang ada. Dengan fokus pada sebuah point dengan pemberian energi positif maka akan mampu berdampak pada energy makro yang ada pada kota. penataan pada suatu spot/ pinpoint tertentu pada kota mampu memberi dampak besar pada kualitas kehidupan kota tersebut

\section{METODE}

\section{Metode Penelitian}

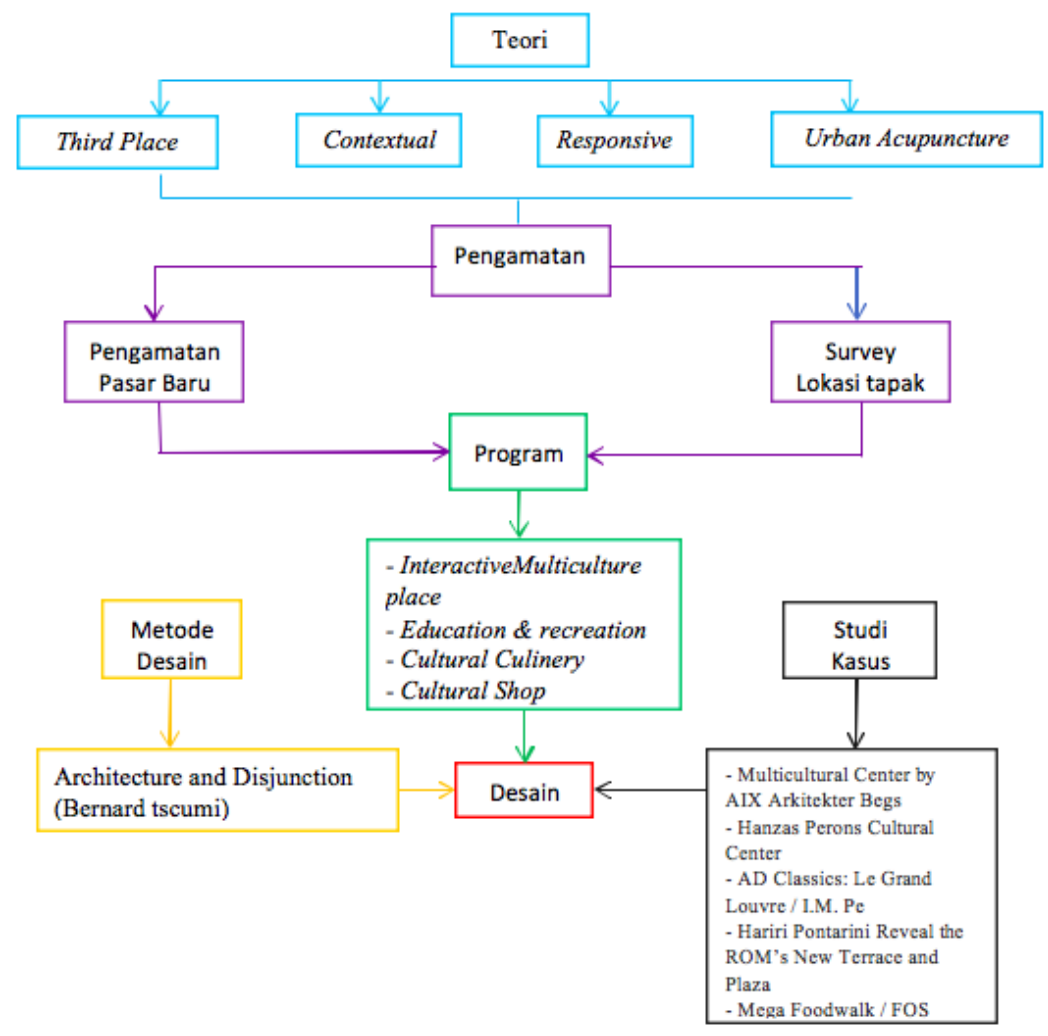

Gambar 1. Sistematika Metode Penelitian

Sumber: Pribadi, 2020

Dalam metode penelitian ini membahas tentang bagaimana cara penulis mendapatkan berbagai konsep dan program dalam perancangan. Pertama-tama penulis memahami teoriteori yang bersangkutan dengan permasalahan, lalu dilanjutkan dengan melakukan pengamatan dan mencari data-data. Setelah mencari data dan mengamati lokasi, penulis mendapatkan permasalahan dan potensi, sehingga munculnya program-program untuk mengatasi permasalahan disekitar dengan melakukan perbandingan studi kasus.

\section{Metode Desain}

Dalam merancang desain program, metode desain yang dipakai di program ini adalah metode desain Bernard Tschumi, menurutnya arsitektur merupakan perwujudan suatu konsep. Konsep merupakan hal yang sangat penting. Gambar akan muncul dengan energi dan bukti, namun 
terkadang gambar tidak muncul ketika konsep tidak menghendaki adanya gambar. Jangan melakukan apapun demi desain, tapi bekerjalah hanya demi konsep dengan terus mengulang dan memperbaiki. Teori Bernard Tschumi juga mengadaptasi dari metodologi diagramatic Eisenstein's untuk memanfaatkan interstitial condition diantara elemen-elemen di mana suatu sistem dibuat dari: space, event, dan movement (atau acitivity) yang dapat dijelaskan sebagai berikut:

\section{a. Space}

merupakan hasil pemikiran (ruang ideal) dan praktek sosial (pengalaman ruang) Dalam hubungan dengan program dan movement: Pertama, dalam setiap desainnya menggunakan Envelope karena program dan event yang diwadahinya beragam, kompleks dan tidak tetap. Berfungsi ganda sebagai pelingkup dan event itu sendiri. Kedua, in-between yang merupakan ruang statis yang terbentuk antara ruang-ruang yang diprogramkan yang dijalankan oleh movement yang menciptakan event diluar yang diprogramkan).

b. Event

Event merupakan kejadian yang terjadi berdasarkan yang telah ditentukan atau diprogramkan dan kejadian yang terjadi diluar dari program. Event juga diartikan: insiden, kejadian; item tertentu dalam suatu program. Acara dapat mencakup penggunaan tertentu, fungsi tunggal atau aktivitas yang terisolasi. Hal ini termasuk saat-saat penuh gairah, tindakan cinta dan kematian instan. Keberadaan event adalah independen. Dan murni merupakan konsekuensi dari lingkungan mereka. Dalam sastra, hal ini termasuk dalam kategori narasi (berbeda dengan deskriptif). Dalam hubungan dengan programming, menempatkan program pada konfigurasi ruang dengan cara:

c. Cross Programming, menggunakan konfigurasi spasial tertentu untuk program yang sama sekali berbeda.

d. Transprogramming, mengkombinasikan dua program yang sifat dan konfigurasi spasialnya berbeda.

e. Dispogramming, mengkombinasikan dua program sedemikian rupa sehingga konfigurasi ruang program pertama mengkontaminasi program dan konfigurasi ruang kedua

f. Movement

Movement diartikan sebagai: tindakan atau proses bergerak. Pergerakan tubuh sebagai jalan cerita dari pengalaman ruang. Berupa pergerakan acak (random movement), pergerakan berarah (vectorized movement). Arsitektur dianggap hanyalah sebuah organisme yang secara pasif terlibat dalam hubungan konstan dengan pengguna, yang tubuhnya terburu-buru melawan aturan pemikiran arsitektur yang ditetapkan dengan cermat.

\section{DISKUSI DAN HASIL}

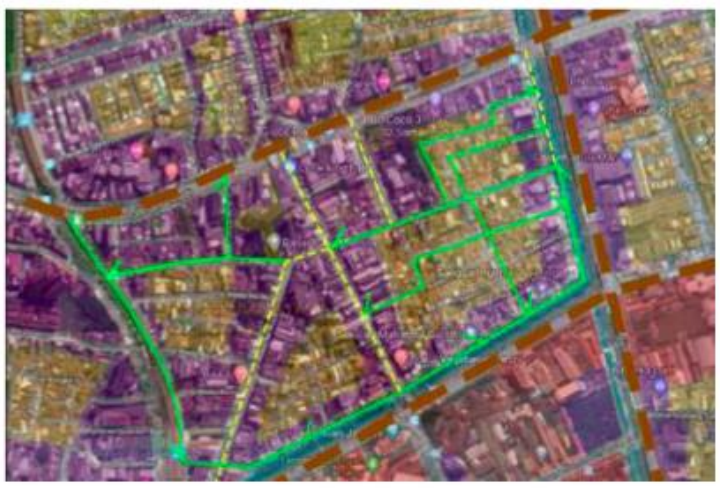

KETERANGAN:

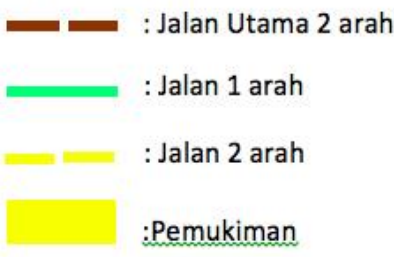

: Kantor,Jasa, Perdagangan

Gambar 2. Analisis Sirkulasi dan Zona sekitar Tapak Sumber: Pribadi, 2020 
Dari data sirkulasi dan zoning di atas tapak berada di antara zona permukiman dan zona perdagangan atau perkantoran. Diharapkan program dapat menarik daya tarik pengunjung maupun warga sekitar yang ingin pulang dan pergi ke daerah Pasar Baru.
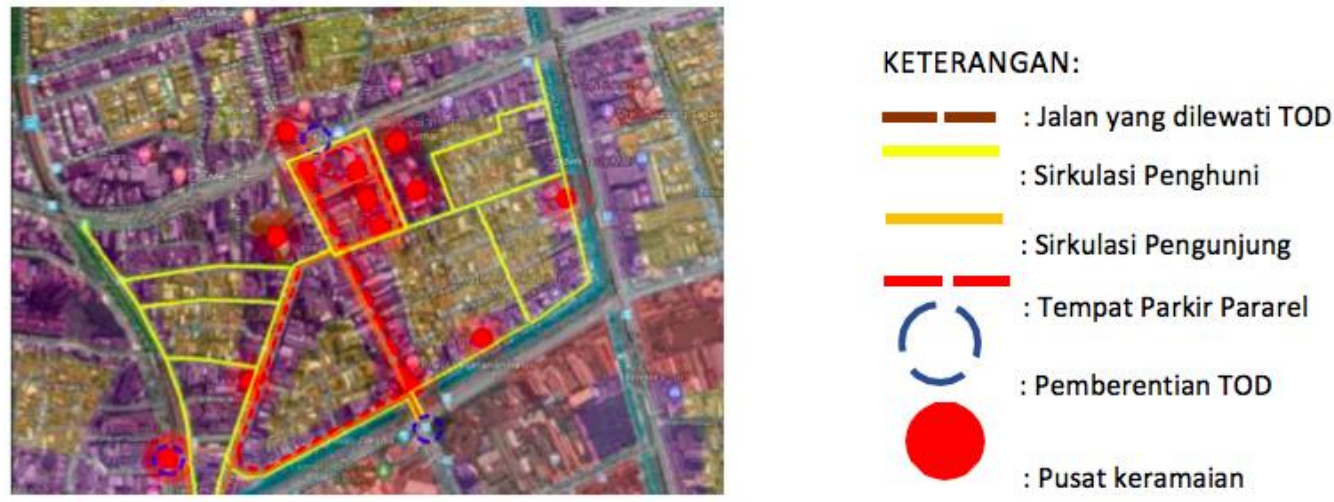

Gambar 3. Analisis Sirkulasi Pengunjung, Penghuni, TOD, dan Pusat Keramaian Sumber: Pribadi, 2020

Dari data di atas terlihat bahwa tapak berada di daerah yang belum dibangunan dan daerah tapak berada di pusat keramaian, dan disini terlihat bahwa pusat keramaian berada di pintu utara Pasar Baru dan di Jl Gereja Ayam, dikarenakan disana terdapat Gedung Parkir Metro Pasar Baru, Pasar Baru, Bakmi Gang Kelinci, Sekolah Ecole De Smarties, dan Gereja Pniel/Ayam, serta Vihara Sin Tek bio, sirkulasi pengunjung berasal dari TOD dan tempat parkir pararel di sekitar Pasar Baru.
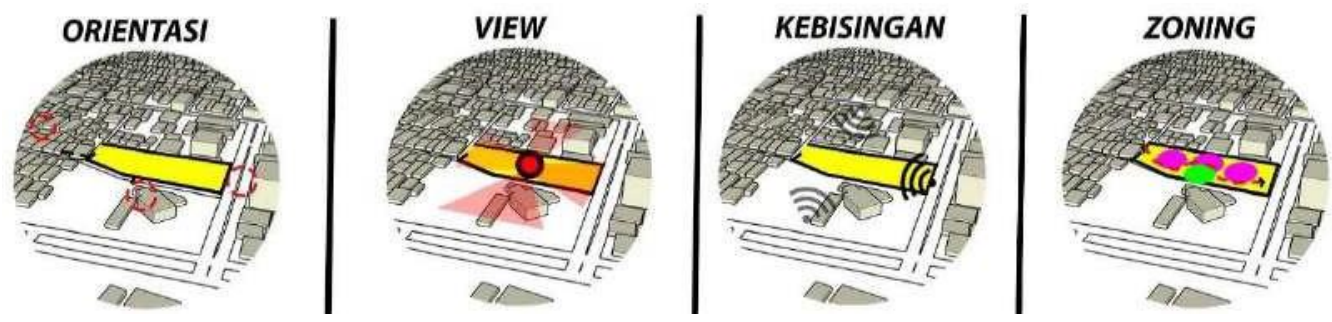

Gambar 4. Orientasi, View, Kebisingan dan Zoning Bangunan Sumber: Pribadi, 2020

\section{a. Orientasi}

Bangunan bererorientasi menghadap Gereja Ayam serta memberikan bukaan terhadap penghuni yang tinggal di Jl. Sentul dan menangkap pengunjung Metro Pasar Baru yang menjadi pusat keramaian di jl gereja ayam, sehingga tersambungnya first place dan second place.

b. View

View bagian utara menghadap Gereja Ayam dan Jl. Samanhudi, bagian timur menghadap Metro Pasar Baru, bagian barat pemukiman, dan selatan menghadap sekolah dan pemukiman. Best view dari bangunan ini yaitu menghadap arah utara yaitu menghadap Gereja Ayam.

c. Kebisingan

Kebisingan terkuat berada di bagian barat bangunan dikarenakan dekat dengan daerah pusat perbelanjaan Metro Pasar Baru dan Jl. Gereja Ayam yang ramai kendaraan dan aktivitas pengunjung.

d. Zoning

Penempatan open space terletak di tengah-tengah bangunan komersil dan di depan main enterance dikarenakan menjadi pusat perhatian serta diharapkan mampu memberi kesan Netral dan mengundang pengunjung untuk masuk ke dalam tapak. 


\section{Transformasi Gubahan}

\section{TRANSFORMASI GUBAHAN}

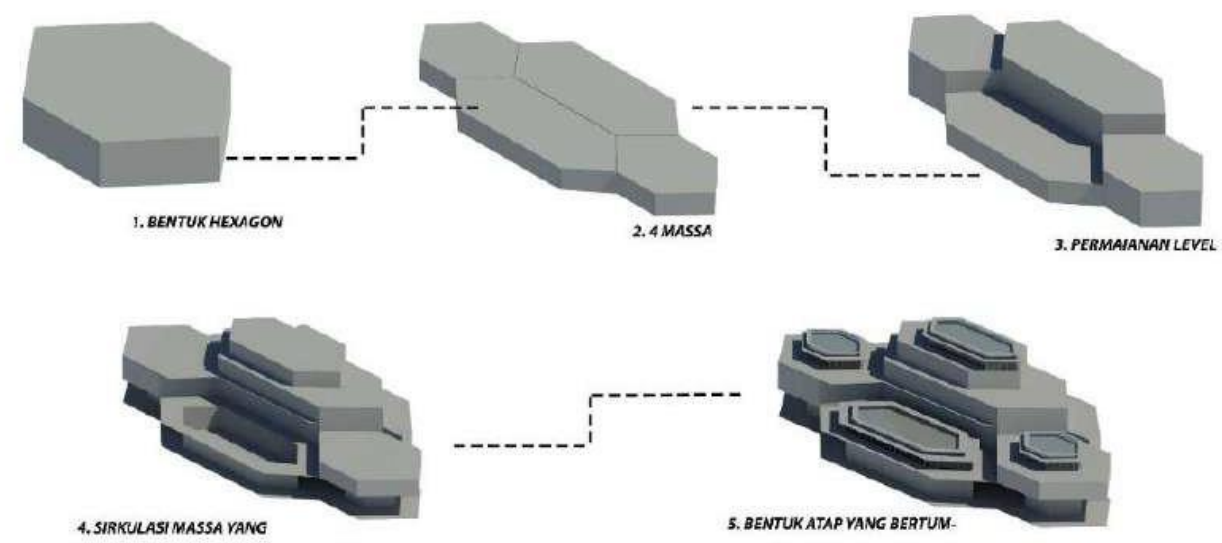

Gambar 5. Transformasi Gubahan

Sumber: Pribadi, 2020

\section{Berbentuk Hexagon}

Bentuk ini diambil karena mengisyaratkan 6 agama di indonesia serta bentuk hexagon juga banyak dipakai diberbagai kebudayaan serta etnis seperti bentuk, pagoda ornamen-ornamen berbagai kebudayaan, dan juga bentuk ini diambil dari bentuk lokalitas dari Gereja Ayam yang juga memiliki segi banyak.

\section{Massa}

Gubahan berasal dari 4 bentuk hexagon yang bermakna 3 kebudayaan atau etnis yang disatukan di gubahan tengah yang berfungsi sebagai bangunan amphiteater, yang dapat dipakai masyarakat menyalurkan berbagai kebudayaan, massa ini juga menjadi main enterance, hal ini bertujuan untuk memberikan kesan netral, yang dimana semua kalangan dapat menikmati.

\section{Permaianan Level Massa}

Permainan level yang berbeda bertujuan untuk bangunan tidak menimbulkan efek Gigantisme dan amphiteater ditengah lebih pendek bertujuan untuk memecah keramaian sehingga pengunjung dapat melihat di massa yang lain, dan juga menghormati Gereja Ayam yang berada di depannya.

\section{Sirkulasi Massa Yang Dinamis}

Sirkulasi lantai 1 dibuat arcade yang bertujuan untuk memberi kesan non formal sehingga mengundang orang untuk masuk ke dalam bangunan, dan disetiap lantainya massa bangunan tersambung lewat outdoor maupun indoor.

\section{Bentuk atap bertumpuk}

Bentuk atap yang bertumpuk bertujuan untuk memberikan pencahayaan melewati skylight, hal ini terinspirasi oleh bentuk mahkota gereja ayam, pagoda, atau bentuk atap masjid yang juga bertumpuk dan memliki pencahayaan. 


\section{Program Ruang}

Di dalam proyek ini terdapat program-program yang diharapkan dapat menyelesaikan permasalahan disekitar seperti:

\section{a. Amphiteater seni}

Amphiteater ini dipakai masyarakat untuk menyalurkan berbagai kebudayaan, sehingga mempunyai Regulars, serta dinikmati semua kalangan Leveler dan bersifat Netral

b. Penjualan Makanan Berbagai Etnis

Menjual makanan berbagai etnis, seperti makananan etnis Betawi, Tionghoa, maupun India.

c. Penjualan Aksesoris kebudayaan

Menjual aksesoris dan souvenir berbagai macam kebudayaan dan etnis, khususnya, etnis India, Tionghoa, Betawi.

d. Perpustakaan

Perpustakaan ini bertujuan untuk mendukung banyaknya sekolah di sekitar tapak serta dapat dipakai bagi semua kalangan.

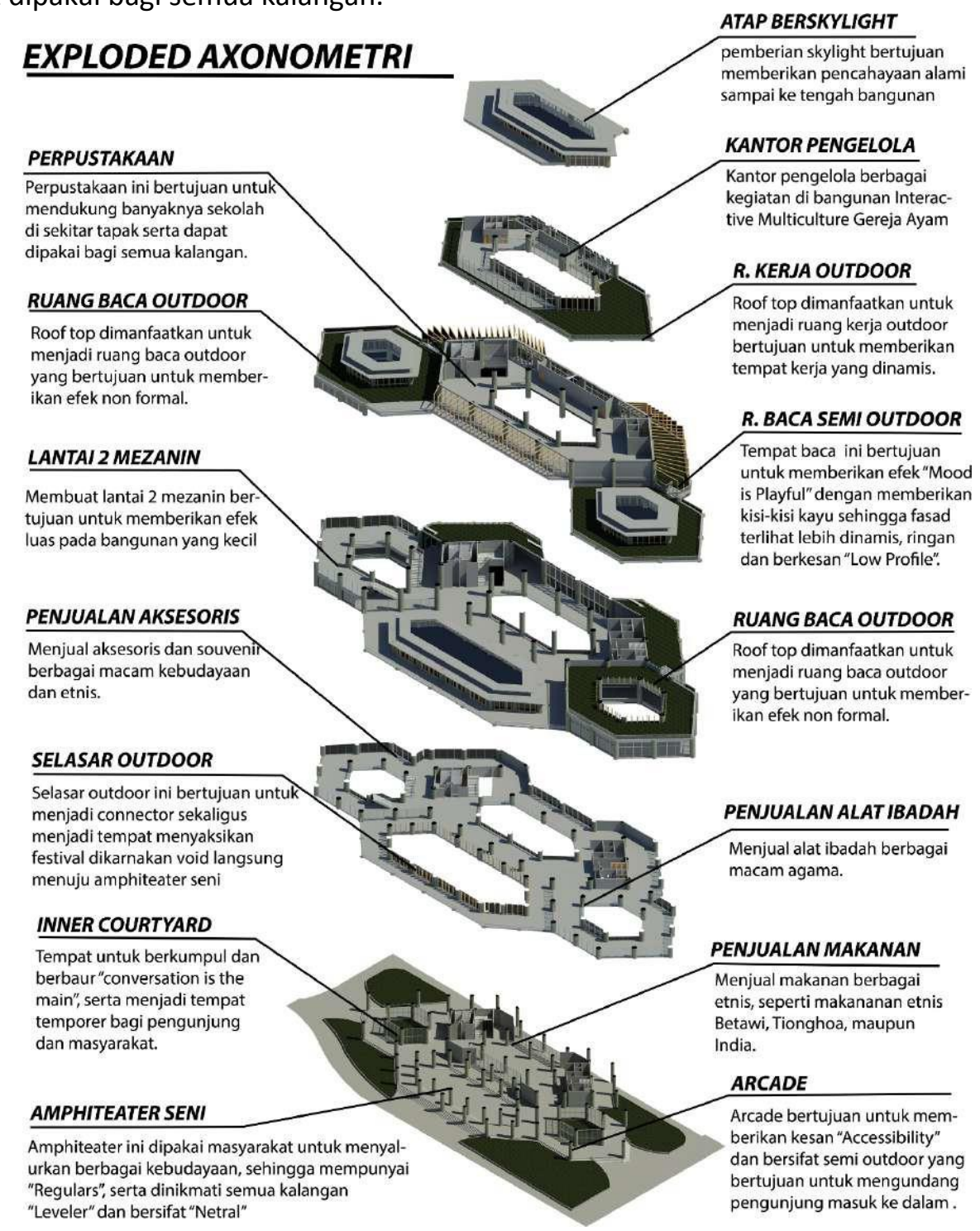

Gambar 6. Exploded Axonometri Tempat interaksi berbagai macam kebudayaan - JL. Gereja Ayam

Sumber: Pribadi, 2020 


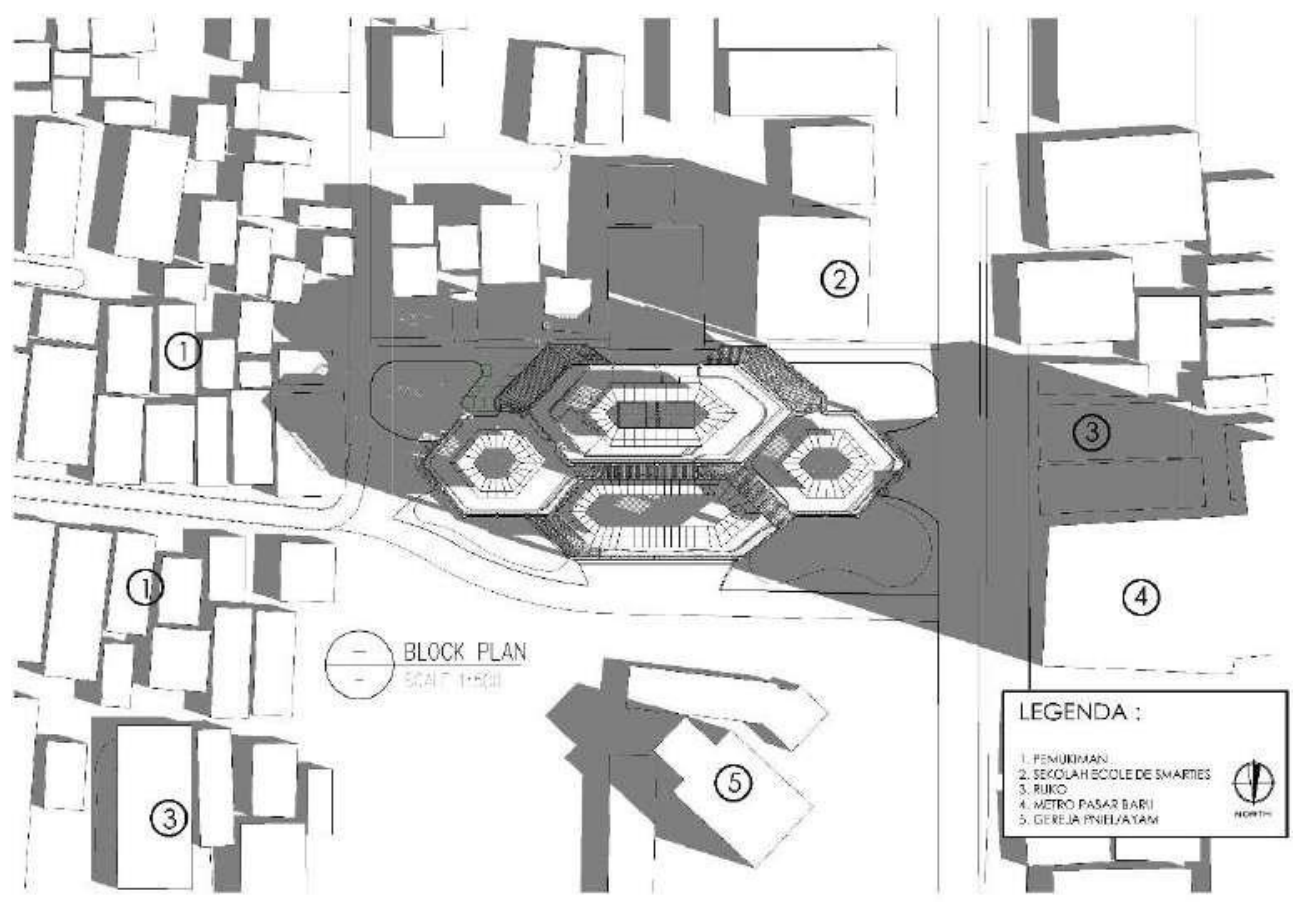

Gambar 7. Block Plan

Sumber: Pribadi, 2020

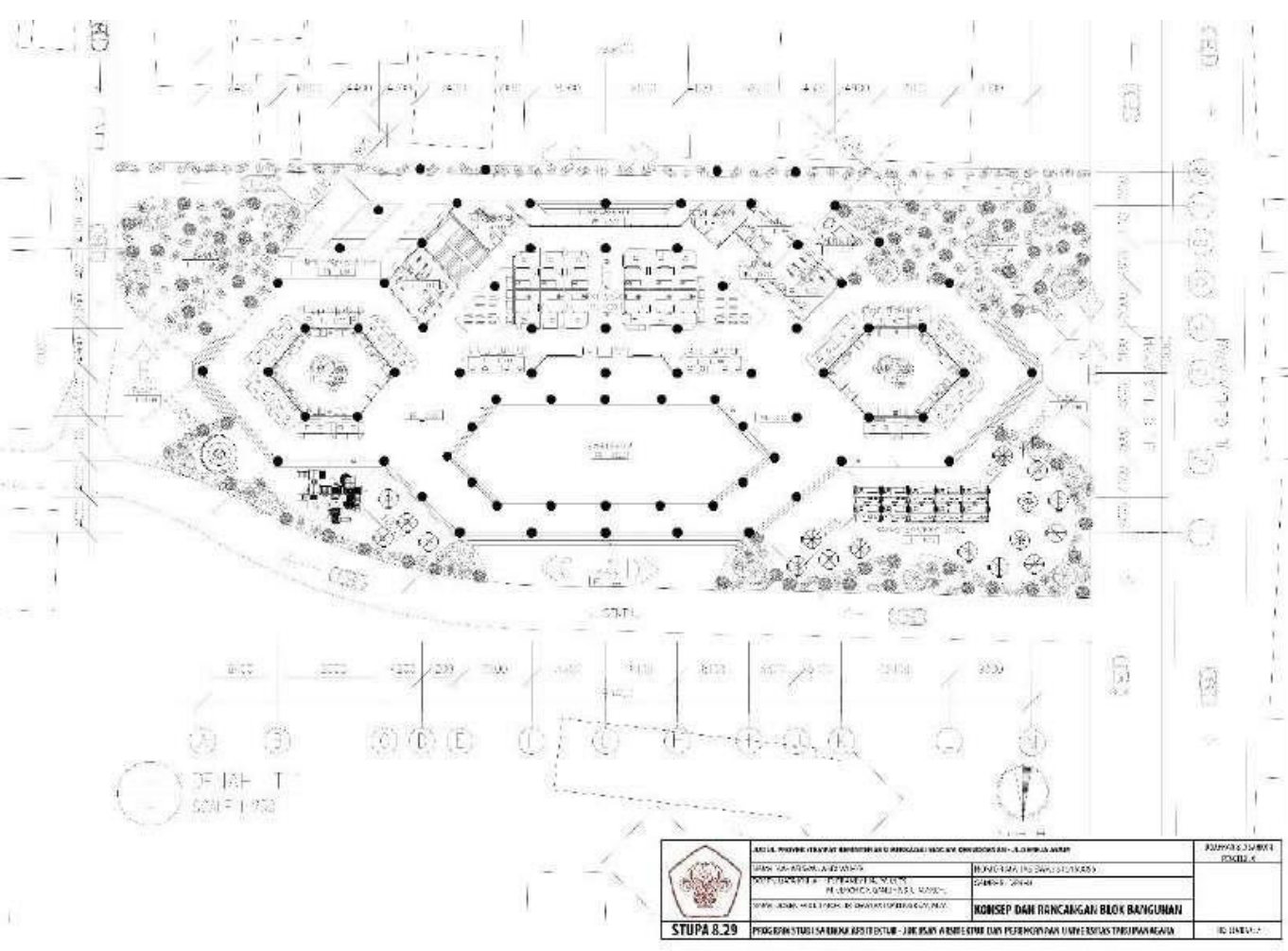

Gambar 8. Denah Lantai Dasar

Sumber: Pribadi, 2020 


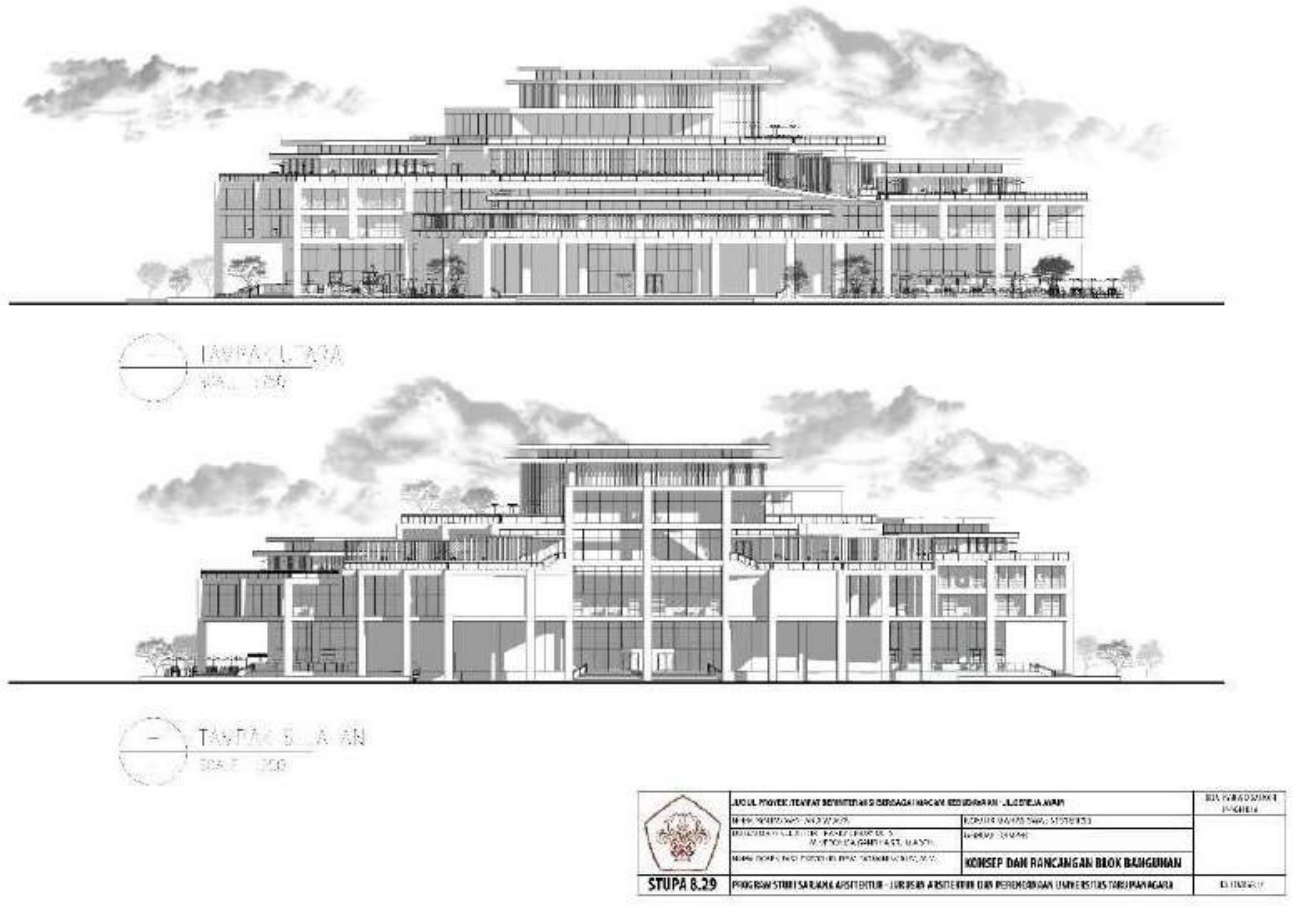

Gambar 9. Tampak Bangunan

Sumber: Pribadi, 2020

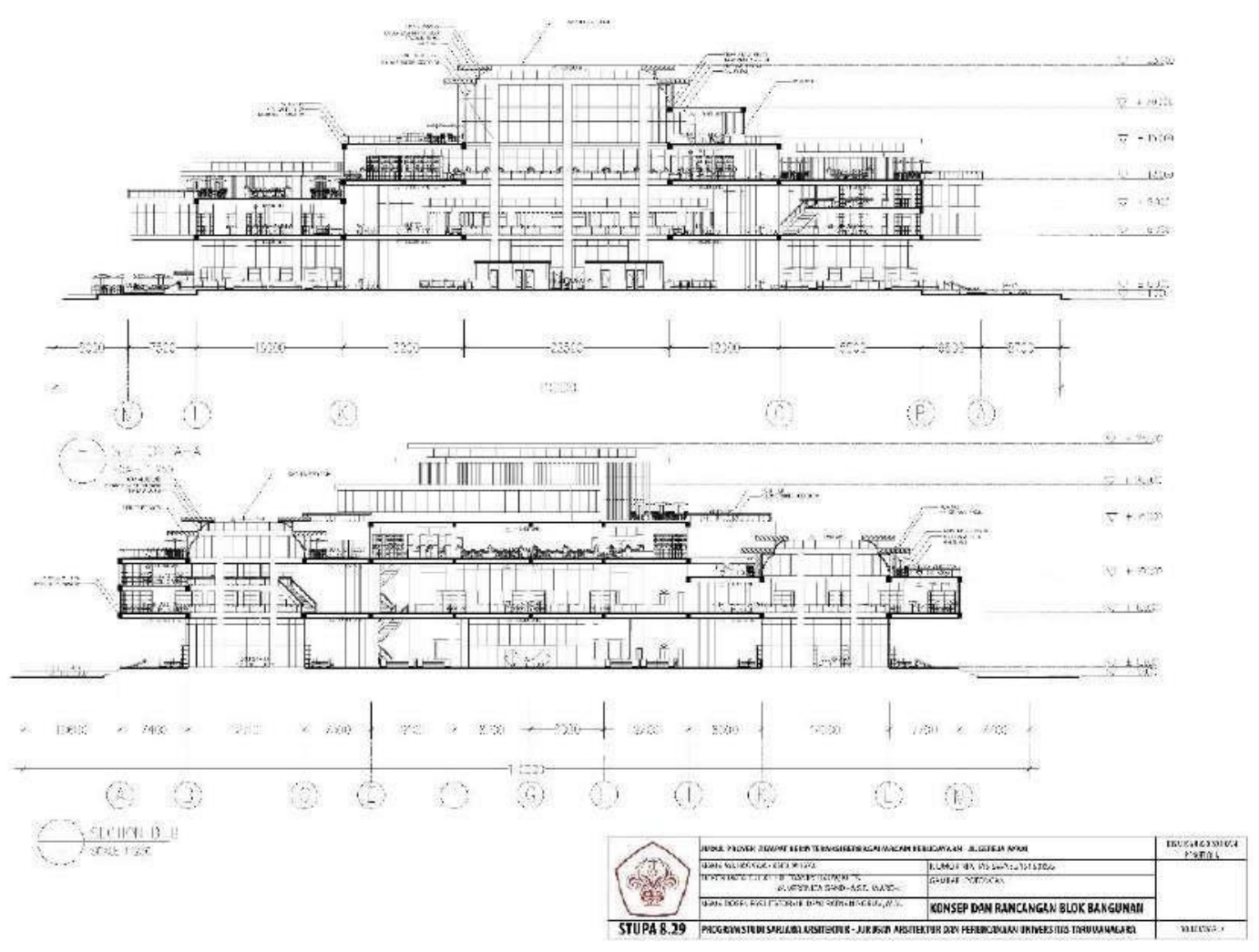

Gambar 10. Potongan Bangunan

Sumber: Pribadi, 2020 


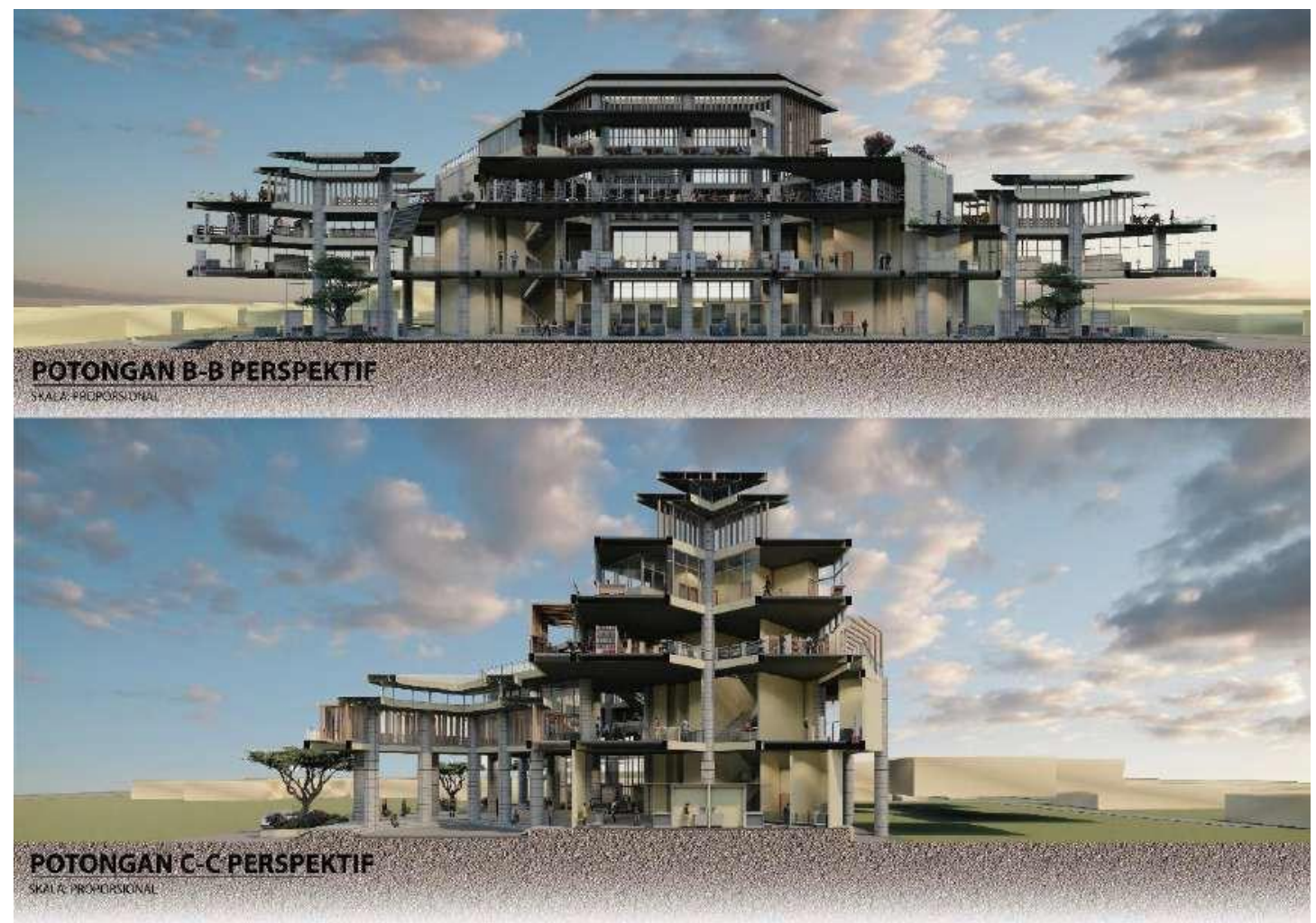

Gambar 11. Potongan Perspektif

Sumber: Pribadi, 2020

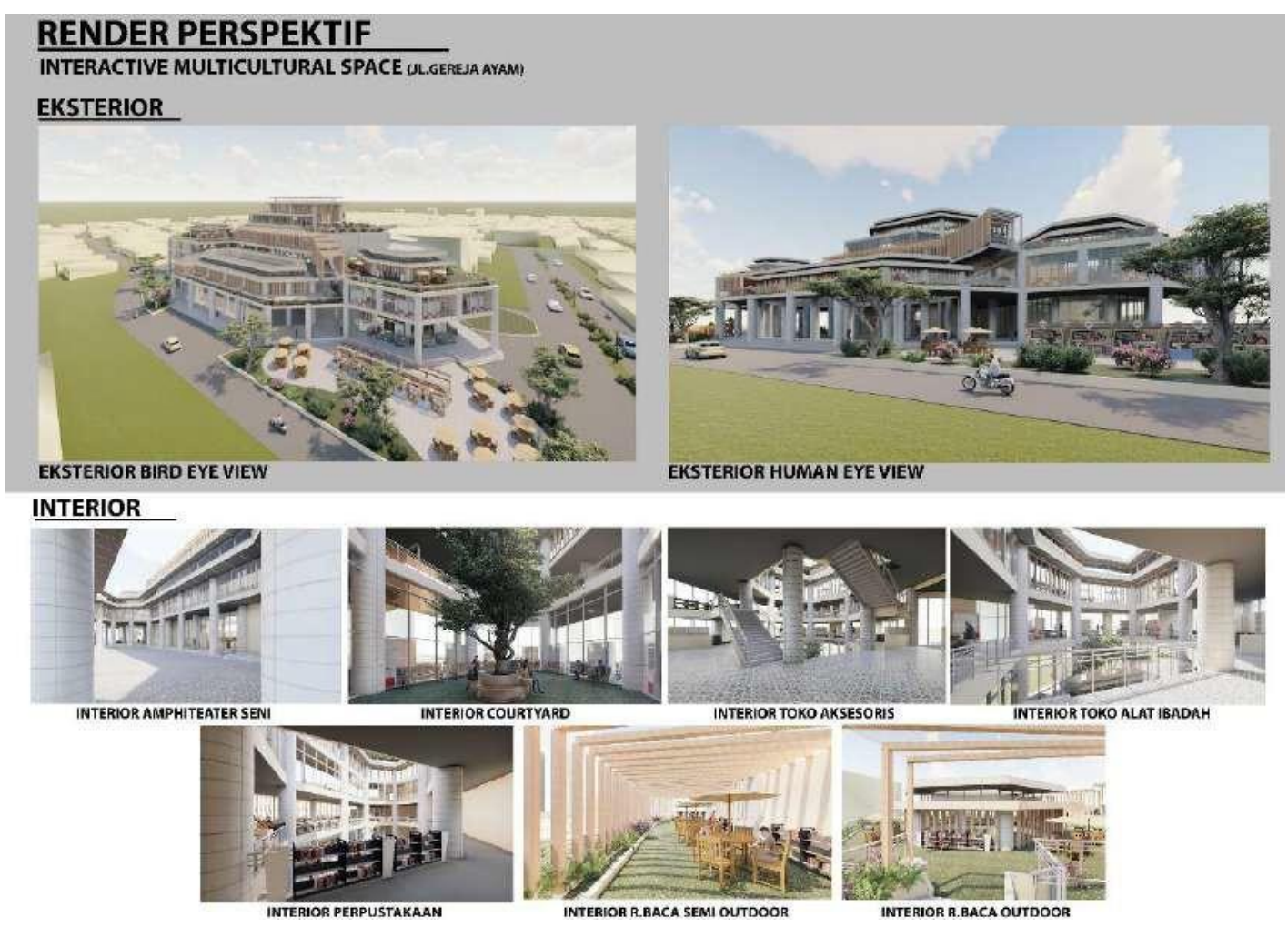

Gambar 12. Perspektif Eksterior dan Interior Bangunan Sumber: Pribadi, 2020 


\section{KESIMPULAN DAN SARAN Kesimpulan}

Dari pembahasan di atas kita tau bahwa Pasar Baru adalah salah satu pusat perbelanjaan terkenal di Jakarta pada jamannya, dan Pasar Baru kaya akan kebudayaan dikarenakan tinggalnya berbagai etnis disana, akan tetapi sekarang Pasar baru menjadi sepi, hal ini berdampak ke kawasan sekitar juga. Proyek ini bertujuan untuk membuat Pasar Baru menjadi eksis kembali dengan menyelesaikan berbagai permasalahan yang ditemukan penulis dan mengangkat potensi kawasan tersebut yaitu kaya akan kebudayaan yang dihasilkan dari berbagai etnis di Pasar Baru.

Program yang dihasilkan adalah membuat Third place di kawasan Pasar Baru dengan memperhatikan unsur-unsur Third place, dan memakai berbagai teori seperti bagaimana membuat kawasan menjadi lingkungan yang responsive (Responsive Environments), membuat kontekstual di kawasan sekitar (Architecture Contextual). Oleh karena itu program - program pada proyek Interactive multicultural space - JL. Gereja Ayam ini diharapkan dapat menjadi Third place, bagi masyarakat dan pengunjung di sekitar. Serta dengan adanya program ini, maka diharapkan kebutuhan-kebutuhan dan permasalahan di sekitar tapak dapat terselesaikan. dan memberikan dampak positif bagi masyarakat di kawasan sekitar.

\section{Saran}

Proyek Tempat berinteraksi berbagai macam kebudayaan ini kurang dalam memperhatikan detail-detail kebudayaan di berbagai etnis baik berupa fasad bangunan serta keterkaitan dengan Pasar Baru. Saran untuk pengembangan proyek ini yaitu perlunya lebih mendalami disetiap detail-detail maupun analisis sekitar untuk lebih mendapatkan kesamaan dan kecocokan yang lebih medalam pada desain. Dan juga untuk dapat mewujudkan usulan proyek diperlukan Kerjasama antara pemerintah dengan pihak swasta dalam hal pendanaan dan pengelolaan.

\section{REFERENSI}

Brolin, C, B. (1980). Architecture In Context. New York. Van Nostrand Reinhold Company. Bentley, I. (1985). Responsive Environments. Routledge. London. Routledge.

Indra, M. I., (2009). Pengembangan Pasar Baru. FT Universitas Indonesia. Diakses 10 Februari 2020, http://lib.ui.ac.id/file?file=digital/123012-T\%2026149-Pengembangan\%20pasarAnalisis.pdf

Lerner, J. (1970). Urban acupuncture. curtiba. Island Press.

Oldenburg, R. (1997). The Great Good Place. Cambridge. Da Capro Press.

Oldenberg, R. (2001). Celebrating the third place. New York. Marlowe \& Company. 
